\title{
The Efforts to Strengthen National Identity Through Ethical Value and Local Wisdom in Oral Literature
}

\author{
Fitrahayunitisna*, Prima Zulvarina \\ Universitas Brawijaya
}

\begin{tabular}{ll} 
A R T I C L E I N F O & A B S T R A C T \\
\cline { 2 - 3 } $\begin{array}{l}\text { Keyword: } \\
\text { oral literature } \\
\text { ethic and local wisdom } \\
\text { national identity }\end{array}$ & $\begin{array}{l}\text { Research shows that oral literature contains ethical values and local wisdom. However, the } \\
\text { existence of oral literature is getting weaker with the changing of the era. Therefore, to } \\
\text { strengthen national identity, oral literature needs to be revived. The main goal is to } \\
\text { improve the character of the young generation which is the Z generation. Efforts that need } \\
\text { to be done is mediatization of oral literature and integrate oral literature into the college } \\
\text { curriculum. The mediatization of oral literature needs to involve digital media, as well as in } \\
\text { its dissemination it requires social media. Meanwhile, integration into the college } \\
\text { curriculum can be done by insert to the Indonesian language course. }\end{array}$
\end{tabular}

(c) 2017 ISLLAC Journal. All rights reserved

\section{INTRODUCTION}

Indonesian people are basically an oral tradition people. The oral tradition has already applied starting from the Pre-literacy era and it still exists until now although the speakers tend to be decreasing. The Indonesian oral tradition has special characteristics and valuable values for daily life. One of the parts of oral tradition is oral literature. Ong (2013:19) stated that oral tradition has given strong and beautiful verbal performance which has a high value of humanity and artistic.

The Indonesian oral literature's values are still relevant to apply in the daily life. Because it came from the basic of nation culture, the oral literature values can be used to strengthen national identity. The decreasing of oral literature's speaker makes the literature less popular right now. Although there is so many research conducted regarding oral literature, the result of the research is still only documented and does not give any contribution to the society especially young generation.

The young generation is the generation born in the digital era. They called " $\mathrm{Z}$ " generation (McCridle dan Wolfinger, 2011). The information right now comes across the country around the world without any borders through digital technology. However, the broad digital information still has any weakness, especially for the "Z" generation. The weaknesses are the lack of awareness of the younger generation to the environment and the lack of awareness of a traditional value which is the character of national identity. So that, it needs something that can bring back the sensitivity of the " $\mathrm{Z}$ " generation especially the moral value. The moral value can be gotten from the oral literature which is derived from traditional culture.

The oral literature has the specific function to educate the people. So that, it has specific values about ethics and local wisdom. However, those values would not be able to transfer to the " $Z$ " generation effectively if there is no up to date and interesting formula. Using digital technology will be effective to transfer the value of oral literature because the " $Z$ " generation could not be separated from the digital culture. They use digital media, social media, and technology in everyday life.

Based on those explanations, this article will explain about the following things: (1) How is the existence of oral literature? (2) How are the ethics and local wisdom contained in oral literature? (3) How are the efforts to strengthened national identity through ethics and local wisdom in oral literature? While the scope of the national identity is among " $Z$ " generation. The objective of writing the article is to describe ethics and local wisdom in the oral

\footnotetext{
${ }^{*}$ Corresponding author.

E-mail addresses: fitra_3006@ub.ac.id (Fitrahayunitisna)
}

2597-7385/ @ 2017 ISLLAC Journal. All rights reserved. This is an open access article under the CC BY license (http://creativecommons.org/licenses/BY/4.0/).

19| ISLLAC : Journal of Intensive Studies on Language, Literature, Art, and Culture 
literature that can be used to strengthen national identity. This article also describes the efforts to strengthened national identity through ethics and oral literature.

\section{THE EXISTENCE OF ORAL LITERATURE}

The research about oral literature in Indonesia is a blue ocean. It is still interesting to dig deeper because Indonesia is the country that rich in cultures and have a lot of oral literature. Although the oral literature has been observed since colonial era by G.A.J Hazue in 1897 until now leaded by Danandjaya and Kuntjoroningrat (Danandjaya, 2002: 10), still so many oral literatures are untouchable. Besides, oral literature derived from folklore doesn't build as major studies but it still becomes minor studies in anthropology, philology, musicology, theology, etc. In order to develop oral literature, we need to observe its values in many aspects. Especially, we need to observe the applications and the usage of the research result to education, arts, culture, and nation aspects.

The existence of oral literature is getting down nowadays. This can be happened because of the changes of the era from oral to literary tradition (Ong, 2013) and now transformed into digital tradition. The other problem is the globalization nowadays makes the people think about homogeneity that can make the oral tradition becomes rare. The oral tradition as the people entertainment is now changed into text and digital or other technology. The habit of telling the story of folklore and singing lullaby of folksong as an entertainment for the children before sleeping now changed into watching television or video on social media. It also happened to the oral literature as the function of education. The media changed from oral tradition into a textbook in formal education.

The oral literature's speaker is now decreased and the existence of the literature will be threatened because of the change of era. Parents are not giving any advice to their children through oral literature as the bedtime story. The oral literature tradition is not popular anymore today because it does not match the recent era. People tend to interest in anything that involves technology. They like to watch more movies or other entertainment on social media like Youtube, Instagram, and Facebook.

The values of oral literature and tradition of telling a story can be revived. Since there are so many researchers about oral literature and the results are well documented, it needs to be reintroduced to people and young generation to remain about forgotten values of the nation. The documentation of oral literature resulted in the bibliography that contains the title of oral literature completed with annotation and summary of the story. Unfortunately, the documentation is only kept in the library, research center, and language center. Endraswara (2009:23) stated that there are so many folklore researchers in Indonesia but it is only to fulfill the target of the project.

There are so many researches about oral literature that has been published in the book and journal. But still, it does not mean that it will spread effectively to the people. Some people will try to find about oral literature in book and journal, but only those who have an academic interest. So, it needs some effective solutions in order to spread the oral literature effectively by digital to strengthened national identity.

\section{THE ETHICS AND LOCAL WISDOM IN ORAL LITERATURE}

The phenomenon of Indonesian society involves forms of oral literature such as fairy tales, legends, myths, traditional speeches, prayers, mantras, poems and folk poetry, rhymes, folk songs, children's songs, and so on. Of the various forms, there are some who survive and some are not. Some are still preserved with revitalization by artists such as folk songs and children's song games. Some other like fairy tales and legends mediate into text and pictorial stories for children's books. These are the proof that people realizes that Indonesian culture can be applied to the entertainment and education.

Dananjaya (2002: 4) conveyed that the functions of folklore among others are as educator media, solace, social protest and projection of desire. The function of oral literature as an education media represents that oral literature has important values for society. The values can be ethics and local wisdom. Ethics is a philosophy that reflects morality, while the moral contain views about moral values and norms embodied in a society (Suseno, 1991). The morality teaches about the meaningfulness and rules of how humans should live and live to be good human beings. Moral values can be very diverse in oral literature. It depends on the tribes, customs, and cultures possessed by the Indonesian nation. Thus, ethics tests which moral should be followed when it faced a particular social situation in order to get responsibility.

Amir (2013: 40) also said that one of the functions of oral literature is a media of education to socialize and convey values. He added that there is an educational process in oral literary performances like the older one giving advice to the younger, giving good examples, giving a message of wisdom and exemplification. In the process of oral literature performances, there are ethics and local wisdom learning. Learning about ethics occurs when the audiences who come to learn, know and understand the social norms prevailing in the community so that they can interact socially with each other in accordance with the values and moral norms. Meanwhile, learning about local wisdom occurs when the audience can understand, and implement messages of wisdom and example of oral literature performances.

Research conducted by Setiawan (2015) about the moral value in oral literature in District of Ngawi found that the legends in Ngawi have moral values that show local wisdom and norms which have typical of the Indonesian culture. The moral values that indicate local wisdom include the value of understanding, the value of responsibility, the value of the soul of the knight, the value of manners, the value of simplicity and humility, the value of kinship, and the value kegotongroyongan, value of helping others, the value of sincerity, submission, and obedience. The values in the oral literature are still very relevant and useful to be taught to the Indonesian people. 
Another research of oral literature was conducted by Citraningrum (2012) about moral values of the folklore of the Osing community in Banyuwangi. The results are not much different from Setiawan (2015). However, the research found the moral value of the natural environment that includes preserving animals, preserving rivers, and loving plants. This proves that ecological criticism also a part of oral literature. The function of oral literature as education and ecological criticism is represented by folklore in the Banyuwangi. Folklore in Banyuwangi teaches us about ethics in respecting nature. It also teaches society to aware of ecology and how the importance of ecology for human survival. The function of oral literature that contains local wisdom as a means of education, criticism, projection system, identity marker, and instrument of the legalization of institutions and cultural institutions affirmed by Maspaitella (2006) in his research on oral literature in District of West Southeast Maluku in the form of traditional speech. In her research, she mentioned that the message in the oral literature contained criticism and advice that is useful to form a pattern of life togetherness, mutual respect, helping each other and appreciating the culture. While, the referential meaning is conveyed through various ethics that connect human with God, nature, fellow, animals, plants, and certain object.

The same thing is also said by Amir (2013: 21) that oral literature keeps local wisdom, traditional thought, moral messages, and social and cultural values. Local wisdom is the great values belong to society in a particular culture. Astra (2004: 111) conveyed that local wisdom almost is equated with the cultural identity of a nation. The local wisdom that exists in various oral literature in Indonesia needs to be explored to strengthen national identity. Furthermore, Astra said that local wisdom in various cultures in Indonesia is still very relevant to overcome the problems caused by globalization, so it needs revitalization for the local wisdom.

\section{THE EFFORTS TO STRENGTHEN NATIONAL IDENTITY THROUGH THE ORAL LITERATURE}

This section will discuss the efforts to strengthen national identity through oral literature. There are three things that will be concerned by the writers as the effort to strengthen national identity through oral literature focusing on the $\mathrm{Z}$ generation. Those are (1) Mediatization, (2) Integrating oral literature to the college curriculum.

\section{Mediatization}

Oral literature in Indonesia still exists. However, the tradition of oral literature has changed a lot. Some oral literature has become a tourism commodity. It is just shown to attract the attention of tourists. To find the original oral literature, we must visit a particular area of the countryside. It is also conveyed by Amir (2013: 174) that oral literature exists only when performed; people and performers come during the show, they sit together at the same place and time. The performer brings oral literary performances, the people enjoy. Oral literature is shown to be enjoyed by people; otherwise, the artist or performer performs oral tradition as it is known and people wanted.

In the recent time, the oral literature packaging is more various and interesting, for example in the form of a collection of pictorial stories, comics, and even modern and contemporary performances. There has been an attempt to revitalize and mediate to maintain the existence of oral literature. However, not all of those forms of the oral literature can be effectively reached the whole generation. Such as comics and pictorial stories are only enjoyed by children, revitalized oral literary performances are watched by adults and young people but it is only on certain occasions. Therefore, a more diverse, unique, and interesting mediatization is needed, so that the oral literature forms can be enjoyed and accessed easily. The mediatization, in this case, means transferring oral literature to alternative media or other media. Of course, the mediatization has to come into contact with digital media that has become part of people's lives, especially the young generation.

Types of oral literature are not only performances and arts, but also indigenous speech, poems and folk poetry, children's songs or even praise songs for the death or song to catch tigers or wild animals, and common activities such as conversations among community members (Amir, 2013: 4). The oral literature that is understood by the common people is the oral literature in the form of art and literature such as folklore, myth, artistic performances, pantun, and so on. Those kinds of oral literature as stated by Amir are not well mediated in an attractive model. It has an impact on the existence of the oral literature of traditional speech, poems and folk poetry, even the children's play songs.

The young generation today is not familiar with the three types of oral literature such as traditional speech, poems, and folk poetry, and children's play songs. The three types of oral literature need to be mediatized in a unique and interesting method. The mediatization can be in the form of short films, comic, a smartphone application, and memes. The digital media can be an effective media to disseminate the oral literature. One of the examples the usage of digital media to spread the oral literature is the fable film from Malaysia entitled "Pada Zaman Dahulu". It is not only broadcasted in Malaysia but also in Indonesia.

Traditional speech, poems and folk poetry, and children play a song can be mediated through film or short video with poetic musicals. The traditional speech usually can be found in traditional ceremony spoken by the local leader. Short films can be packed attractively by digging traditional speech that sounds familiar to the young generation. Meanwhile, poems and folk poetry can be mediated in a poetic musical short video. The children play a song can also be mediated through the interesting film.

In addition, comics can also be become the media to introduce oral literature. Comics are pictorial or cartoon stories in magazines, newspapers, or books that are generally easy to read. A comic that usually popular in Indonesia comes from Japan. The themes of the comics are usually about love, friendship, and heroes. The character of the comics is also represented Japanese culture. In the recent time, Aji Prasetya, a comic artist from Indonesia has published several comics about national issues, critics, independence war, colonialism, history, and so on. It will be better if the concept of the oral literature applies to the comic. So, the themes of oral literature also involved in comic. 
Smartphones become the products that are currently owned by children, adults, and also parents. In the smartphone, of course, there are so many applications. Oral literature can be mediated through the application in the smartphone. The apps can contain story taken from folklore. They can be created like an existing webtoon apps.

The other media to spread the discourse is a meme. Memes often appear in online media, memes are ideas that spread from one person to another through the image in online media. The purpose of disseminating memes are varied, such as mockery, criticism, entertainment, advice, and so on. The mediation of oral literature such as traditional speech and children's play songs can also be created in the form of memes. This is because memes have similar character when viewed in terms of function. The function equally aims to spread the discourse in the form of ridicule, criticism, entertainment, advice and so on.

Meme's mediatization will be more interesting and understandable by the young generation. Besides, the spread of meme is very quickly through online media. The spread of oral literature nowadays can be so fast through online media, and it is one of the effective ways to introduce oral literature to the young generation. It is better if oral literature is combined with modern arts. By combining those two things oral literature will be survived (Amir, 2013:185). Oral literature will not be well spread if it does not continuously mediate from time to time.

The mediatization of oral literature with the digital media nowadays is to spread and introduce the ethics and local wisdom in oral literature to the youngsters. The spreading of this discourse is intended to give influence and remind to Indonesian characteristics of the young generation. Therefore, the efforts to strengthen national identity through oral literature require an interesting media and close to the habits of social life.

\section{Integrating into college Curriculum}

So far, oral literature in college is only studied in certain disciplines. These disciplines such as anthropology, philology, sociology, musicology, ethnolinguistics, and are also an as minor subject in other disciplines related to the humanities, the arts, the social, and the culture. Then, other disciplines related to science are not so familiar. In fact, many values can be got from oral literature.

The meaning of education is humanizing human beings, that is, making human beings become virtuous and dignified who can live a life as a good human. For that reason, the goal of education is not only to transfer the knowledge. However, the portion of character education in a college curriculum is less than the primary and secondary schools. Nevertheless, the effort to improve character education to strengthen the identity of the young generation can be done with the integration of oral literature into the general course.

One of general course that should be studied in university in Indonesia is the Indonesian Language. Government law number 12 by the year 2012 stated that the general courses that should be studied in the university are Indonesian Language, Religion Education, Pancasila, and Civics Education. Through these four general courses, it is expected to achieve the goals of national education. In this case, oral literature can be integrated to Indonesia Language as a general course.

The integration of oral literature into the Indonesian Language as the general course can be applied to the several skills such as writing, speaking, listening and reading. But in this article, the writer will be a focus on writing skills. Writing skills in college is more emphasized on scientific writing skills. As academic demands, students are expected to be able to express their ideas in scientific and popular writings. Therefore, the lecturer as a facilitator is expected to make the learning scenario of writing scientific work with based on ethics and local wisdom in oral literature. The scenario of learning to write scientific papers will be offered in detail by the writers as follows.

The learning scenarios contain an assignment of writing scientific papers based on local wisdom, writing plan, field research (observation and interview, presentation of field result, and writing process). The instrument used in this learning process is digital media.

The first scenario, (1) the lecturer assigns the writing assignment of scientific writing based on ethics and local wisdom in the oral literature that exist in the surrounding environment, this task can be done in groups and individuals. (2) the lecturer provides knowledge of the oral literature, characteristics, types, and functions in society, (3) the students reflect and recall the oral literature they have in their hometown, (4) after finding oral literature to write, students make plans to write oral literature with the direction and guidance from lecturers such as determining themes, subthemes, and titles (what specifically wants to be written in oral literature, such as moral values, local wisdom, or ethics in folklore). The expected outcomes in this learning scenario are (a) the students know the oral literature that exists in the surrounding area, (b) the students are able to understand the characteristics, types, and functions of oral literature, (c) the students are able to make the framework of scientific work.

The second scenario is field research, (1) the students are assigned to the field to observe, interact, and interview the local community where oral literature still exists, (2) students are assigned to take documentation to be used in the presentation of work. In the form of field research, the students are expected to the following things such as, (a) the students are able to study the prevailing social ethics in the local community. The process of learning about ethics occurs when students come to the location for observation and interviews. In the process, students need to interact directly with people in the real world rather than cyberspace, so they will learn how to actively communicate, open conversations, get to know the other person, and learn about ethics. The next achievement is (b) the students are able to understand the value of local wisdom from the oral literature that exists in a society when observing and getting information directly from them.

The third scenario, it is called the presentation of field results, (1) students are assigned to present the results of observations and interviews in front of the class by using digital media i.e. short video or meme. The results of observations and interviews about local wisdom can be made in the form of memes, whereas folklore (myths, legends, and fairy tales) containing local wisdom values can be presented in short videos. It attracts and challenges students' 
creativity. (2) After the presentation, students are assigned to upload memes or short videos to social media (Instagram, Facebook, or Youtube). The best score can be determined by how many of their meme or short video. It motivates students to compete and create creative ideas in transforming oral literature to digital media as well as possible. The expected achievements of this learning are (a) students are happy and proud to introduce oral literature that is the nation's cultural heritage to peers and the wider community both in presentation and through social media, (b) students are able to appreciate local ethics and wisdom that exist in oral literature, and (c) students can apply the relevant ethics and local wisdom in daily life to strengthen their national identity.

The fourth scenario is the writing process, (1) the students develop the writing plan into the framework of the essay, (2) the students develop the framework by analyzing the data from the observation and the interview into a scientific work. (3) The students edit his / her writing by observing the accuracy of spelling, the accuracy of sentences and paragraphs, as well as the ethics and style of scientific writing applied to the writing of quotations and references. The expected accomplishments in this scenario are (a) the students are able to create the framework of the essay, (b) the student is able to develop the framework of the essay into a proper scientific writing of spelling, appropriate use of sentences and paragraphs, and quotes.

The outputs of the four learning scenarios are (1) the mediatization of oral literature into the digital form by the students, (2) the dissemination of ethics and local wisdom of oral literature that has been transformed into digital media in social media, (3) scientific work on ethics and local wisdom in oral literature. Those outputs are expected to improve the character of the students to be more ethical and have local wisdom characteristics as the identity of the nation's generation. In addition, the dissemination of oral literature that has been mediated in social media can provide a new idea as well as influenced by the wider society to strengthen national identity.

\section{CONCLUSION}

The efforts to strengthen national identity can be applied by using oral literature. Some researchers show that there is a close connection between oral literature and ethics and local wisdom. As one of the functions of oral literature is to educate the community, it contains the values of local ethics and wisdom. However, it cannot be denied that the popularity of oral literature is decreasing with the changing of the era.

Therefore, oral literature needs to be revived to strengthen national identity. Its main goal is to enhance the young generation or " $Z$ " generation that grows in the digital age, becoming a generation that has a character reflected national identity. In this case, the effort that needs to be done is to mediate the oral literature and the integration of oral literature into the curriculum in university.

The mediatization of oral literature needs to use digital media. Oral literature mediatization can be done by transforming into short movies and videos, memes, and comics that can then be disseminated through social media and applications in smartphones. Meanwhile, integrating oral literature in the college curriculum can be done by inserting the material into Indonesian Language course.

\section{REFERENCE}

Amir, A. (2013). Sastra Lisan Indonesia. Yogyakarta: Andi Offset

Astra, I.G.S. (2004). Revitalisasi Kearifan Lokal dalam Memperkokoh Jatidiri Bangsa di Era Global. I Wayan Ardika dan Darma Putra (eds). Politik Kebudayaan dan Identitas Etinik. Bali: Fakultas Sastra Universitas Udayana, Balimangsi Press

Citraningrum, D.M. (2012). Representasi Nilai Moral Masyarakat Using Dalam Cerita Rakyat Banyuwangi. Thesis not published. Malang: Universitas Negeri Malang

Dananjaya, J. (2002). Foklor Indonesia: Ilmu Gosip, Dongeng, dan lain-lain. Jakarta: Pustaka Utama Grafiti

Endraswara, S. (2009). Metode Penelitian Foklor: Konsep, Teori, dan Aplikasi. Yogyakarta: Med Press

Maspaitella, M. (2006). Sastra Lisan Nyanuk Pupule Sebagai Ungkapan Tradisional Pada Masyarakat Olilit Timur Kabupaten Maluku Tenggara Barat. Thesis not published. Malang: Universitas Negeri Malang.

McCrindle, M and Wolfinger, E. (2011).The ABC of XYZ: Understanding the Global Generations. Australia: UNSW Press

Ong, W.J. (2013). Kelisansan dan Keaksaraan (Orality and Literacy). Translated by Rika Iffati. Yogyakarta: Gading Publishing

Setiawan, D.S.A. (2015). Nilai-Nilai Moral Dalam Legenda Di Kabupaten Ngawi (Sebuah Kajian Sosiologi Sastra). Thesis not published. Malang: Universitas negeri Malang.

Suseno, Franz Magnis. (1991). Etika Sosial. Jakarta: Gramedia Pustaka Utama. 